\title{
NUOVI APPROCCI TEORICI E SPERIMENTALI ALLA SCOPERTA DI FARMACI
}

\author{
Nota del s.c. MARTINO BOLOGNESI (*)
}

(Adunanza del 19 gennaio 2012)

\begin{abstract}
SunTO. - Diversi motivi ambientali, demografici ed ecologici suggeriscono che virus noti o sconosciuti continueranno ad emergere negli anni a venire in tutto il mondo, presentando una continua minaccia per la popolazione umana. Gli interventi terapeutici oggi disponibili presentano diverse limitazioni; le campagne di vaccinazione nel terzo mondo spesso incontrano problemi di distribuzione, e raggiungono una frazione insufficiente della popolazione. Per molti virus un vaccino non è disponibile, una carenza che si traduce in elevata mortalità nei paesi tropicali e tra i neonati. Su un diverso fronte, la resistenza dei batteri agli antibiotici è in preoccupante crescita, ed e' spesso associata a infezioni nosocomiali. Di conseguenza, nuove idee e approcci alla scoperta o progettazione di farmaci efficaci rappresentano una priorità della ricerca, per offrire strumenti terapeutici e di prevenzione contro potenziali pandemie. In questo contesto, il nostro gruppo presso l'Università di Milano, in collaborazione con diversi laboratori europei ed extraeuropei, studia le proprietà strutturali e funzionali di enzimi coinvolti nella replicazione di virus a RNA, quali bersagli per la progettazione di farmaci antivirali. La logica alla base della scelta di uno specifico enzima virale parte dall'idea che questi enzimi siano sufficientemente diversi dalle loro controparti umane; in tal modo, bloccando l'enzima del virus con un nuovo farmaco, non si dovrebbero registrare reazioni avverse nell'ospite umano. L'approccio alla scoperta di nuovi farmaci, applicato nel nostro laboratorio, è basato su una precisa serie di fasi sperimentali: i) l'analisi della struttura tridimensionale degli enzimi liberi, mediante cristallografia a raggi $\mathrm{X}$; ii) screening preliminare in silico (computazionale) delle regioni degli enzimi selezionati verso cui la ricerca del farmaco è mirata (ad esempio, i siti attivi dell'enzima); iii) test biochimici e biofisici di inibizione dell'enzima; iv)
\end{abstract}

(*) Dipartimento di Bioscienze, Università di Milano, Italy.

E-mail: martino.bolognesi@unimi.it ; http://users.unimi.it/biolstru/Home.html 
struttura cristallina e analisi di complessi enzima/inibitori; v) test di attività in cellula/in vivo; vi) estrazione di informazioni per l'ottimizzazione della molecola-farmaco. Questo metodo di ricerca si è dimostrato efficace nella scoperta di inibitori a basso peso molecolare di due enzimi chiave del virus della Febbre Gialla (e in parte per il virus Dengue), e di Norovirus. In particolare, per Norovirus abbiamo focalizzato la nostra attenzione sul farmaco Suramina, una molecola attiva e nota da tempo (come farmaco contro la "malattia del sonno"), che era stato selezionato attraverso la procedura biofisica e simulativa sopra descritta. I nostri test cristallografici e di inibizione hanno permesso di evidenziare le modalità di legame dell'inibitore all'enzima, e parametri inibitori funzionali adeguati allo sviluppo di un farmaco. Successivamente, nel contesto di una collaborazione internazionale, abbiamo sperimentato una serie di frammenti molecolari della Suramina, alla ricerca di nuovi composti attivi dotati degli opportuni parametri farmacologici. L'attività di ricerca, che, come descritto, si basa su nuovi approcci concettuali e multidisciplinari, ha portato alla produzione di diversi composti a basso peso molecolare che saranno ulteriormente sviluppati per la produzione di composti antivirali.

ABSTRACT. - New theoretic and experimental approaches to drug discovery.

Environmental, demographic and ecological reasons suggest that either novel or known viruses will continue to emerge worldwide, posing new threats to the human population. Additionally, therapeutic interventions present different outcomes; for example, vaccination campaigns in the Third World often encounter local distribution problems and reach an insufficient fraction of the population. For many viruses no vaccine is available, such that the toll death is high, particularly in tropical countries and among infants. On the other hand, resistance of bacteria to known antibiotics is increasingly a serious threat, often associated to nosocomial infections. As a result, new ideas and approaches to the discovery or design of new effective drugs are a high priority in all civilized countries, to prevent and be ready to face potential pandemics. In this context, our group at the University of Milano, in collaboration with several European and extra-European labs, has been exploring the structural and functional properties of enzymes involved in the replication of $(+)$ stranded RNA viruses as targets for the design of antiviral drugs. The rationale behind the choice of specific target viral is the idea that these are structurally and functionally sufficiently different from their human counterparts; thus, blocking the virus enzyme with a new drug should not be reflected by adverse reactions in the human host. The discovery approach applied in our laboratory has been based on a series of specific experimental steps: i) the analysis of crystal structure of the free enzymes, through X-ray crystallography; ii) in silico (computational) preliminary screening of selected enzyme regions towards which the drug search is targeted (e.g. mostly the enzyme active sites); iii) biochemical and biophysical tests of enzyme inhibition; iv) crystal structure analyses of enzyme/inhibitor complexes; v) in cell/in vivo testing; vi) inference for drug-lead optimization. This research method proved effective in discovering low molecular weight inhibitors of two key enzymes from Yellow fever virus (and partly for Dengue virus), and for Norovirus. Specifically, we targeted Norovirus studying the long known drug Suramin (used in the therapy of 'sleeping sickness'), which was selected through the procedure described above through our in silico docking screenings. Our crystallographic and inhibition assays allowed to highlight the inhibitor binding mode and satisfactory functional inhibitory pa- 
rameters. Subsequently, in the context of an international collaboration, we could test a series of Suramin molecular fragments, in search of new active compounds endowed with suitable pharmacological parameters. The described research activity, which is based on new conceptual and multidisciplinary approaches to drug discovery, has led to the production of several small molecules that will be further developed into antiviral compounds. 